\section{Memória e conquistas históricas}

\author{
Memory and historical achievements
}

\author{
Maria Lucia Barroco \\ Assistente social, professora de Ética Profissional e \\ coordenadora do Núcleo de Estudos e Pesquisa em Ética \\ e Direitos Humanos (Nepedh) da Pós-Graduação em \\ Serviço Social da PUC-SP, São Paulo, Brasil. \\ barroco.lucia@gmail.com
}

Resumo: Este depoimento fez parte da mesa de memória comemorativa dos 80 anos do Serviço Social brasileiro realizada no $9^{\circ}$ Seminário Anual de Serviço Social da Cortez Editora, em maio de 2016. A abordagem privilegia as conquistas éticas da profissão, ressaltando o processo de construção de uma nova ética a partir dos Códigos de Ética de 1986 e 1993.

Palavras-chave: Memória. Ética profissional. Conquistas históricas.

\begin{abstract}
This testimony was part of the memory table to celebrate the eighty-year-old existence of the Brazilian Social Work. Such a memory table was prepared in Editora Cortez's $9^{\text {th }}$ Annual Seminar of Social Work, in May 2016. The approach stresses the ethical achievements of the profession, and it highlights the construction of new ethics from 1986 and 1993's Codes of Ethics.
\end{abstract}

Keywords: Memory. Professional ethics. Historical achievements.

Nesta comemoração dos oitenta anos do Serviço Social brasileiro, resgatamos a história para que nossas conquistas alimentem nossa memória e nossas lutas nos dias atuais. Falar das conquistas éticas da profissão invariavelmente remete aos Códigos de Ética de 1986 e 1993, que romperam com os pressupostos que predominaram durante mais de quarenta anos nos Códigos de Ética do Serviço Social no Brasil.

A trajetória dessas conquistas está entrelaçada ao protagonismo da Faculdade de Serviço Social da PUC-SP nos anos 1980, espaço de minha formação e dedicação ao ensino da ética. $\mathrm{Na}$ graduação, tive o privilégio de ser orientada pela prof $^{a}$. Marilda Iamamoto, que, em 1982 lançava o livro que marcou a maturidade da tradição marxista na profissão (Iamamoto e Carvalho, 1983). Fiz estágio num dos campos-piloto da faculdade, que contavam com a supervisão de nossos(as) professores(as). E me encantei com o estudo da ética, a partir das aulas da professora Vicentina Velasco. Dedico este depoimento à sua memória, por sua contribuição à reflexão ética do Serviço Social. Ela me preparou para ministrar a disciplina de Ética, processo iniciado em 1985.

Falar da importância dos Códigos de Ética supõe deslocar a discussão para os elementos que possibilitaram a sua existência, dizer que a ética profissional não se esgota no Código e que a construção de uma nova ética foi determinada, no âmbito da profissão, por ações práticas e políticas mediadas teórica e eticamente.

A constituição de uma nova ética foi forjada num longo processo de negação 
dos pressupostos teóricos, das formas de atuação e dos valores que tradicionalmente orientaram o Serviço Social. Alimentou-se das experiências de desenvolvimento de comunidade (DC) e de educação popular, do trabalho junto aos movimentos sociais, sindicatos e associações de trabalhadores. Foi influenciada pela Teologia da Libertação e pela crítica marxista trazida pelo Movimento de Reconceituação Latino-Americano.

A construção de uma nova ética decorreu especialmente de um processo de politização e capacitação teórica que marcou o posicionamento político do Congresso da Virada, em 1979, a organização político-sindical da categoria e o amadurecimento da produção marxista na profissão, nos anos 1980.

O Código de Ética de 1986 veio assinalar a existência dessa nova ética, revelando um dos aspectos mais significativos do projeto profissional que construía suas bases de organização política nas lutas sociais: a afirmação do compromisso profissional com a classe trabalhadora. O Código de 1993 preservou as conquistas do Código de 1986, aperfeiçoando suas formas de operacionalização. Esse processo permitiu a crítica teórica e o enfrentamento político dos componentes que historicamente sustentaram o posicionamento ético do Serviço Social: a concepção abstrata e a histórica dos valores; a defesa de uma pretensa neutralidade política, o conservadorismo ético-político e a tendência à moralização da questão social.

Os códigos são elaborações sistemáticas de deliberações éticas da categoria. Um código expressa a concepção ética, os valores e princípios afirmados pela categoria profissional em determinado momento histórico. É uma das formas de objetivação da ética profissional - a sua forma legal. No entanto, seu conteúdo e a direção social de seus valores e princípios são anteriores ao código, pertencendo à totalidade social.

É nesse sentido que podemos entender o significado dos valores do código. Não são valores do Serviço Social, mas são valores incorporados pelo Serviço Social. A origem desses valores é histórica; eles foram construídos historicamente, nas lutas emancipatórias da classe trabalhadora, dos movimentos revolucionários e das forças progressistas. Nós aderimos a tais valores porque nos vinculamos a essas lutas.

Ao mesmo tempo, a ética profissional, em todas as suas dimensões, não é autônoma e isolada da prática política, da capacitação teórica, da intervenção prática em atividades profissionais. A ética é uma mediação de valor que perpassa pelas diferentes atividades exercidas social e profissionalmente. $\mathrm{O}$ posicionamento político do Congresso da Virada foi mediado por valores éticos; a crítica teórica ao conservadorismo profissional implicou avaliações éticas, e a própria materialização dos Códigos de Ética depende de 
mediações éticas que interferem no exercício profissional.

Apesar de mediar diferentes atividades, a ética tem uma relação especial com a política, pois, na sociedade burguesa, a objetivação dos valores éticos ocorre em situações e contextos movidos pela luta política entre ideias e projetos. Nesse campo de luta pela hegemonia, a ética pode colocar os limites à ação política.

Isso remete diretamente à conjuntura atual que manifesta a ausência de limites éticos e políticos para a destruição de todas as conquistas democráticas dos(as) trabalhadores(as), das mulheres, dos negros, dos movimentos LGBT, entre outras lutas progressistas da sociedade brasileira. O rebatimento dessa situação histórica na formação e no trabalho profissional coloca em risco conquistas inestimáveis do Serviço Social brasileiro, relatadas nesta mesa de memórias.

Na edição anterior deste seminário, em 2015, participei da mesa de abertura, discutindo o conservadorismo, ao lado do prof. Michael Lowy. Terminei minha intervenção afirmando: fascistas não passarão! Hoje, podemos dizer que eles conseguiram passar por uma etapa, mas que a história não acabou. Por isso, para o enfrentamento dessa regressão, nossa mobilização política e direção ética são urgentes e necessárias: vai ter luta, fascistas não passarão!

\section{Recebido em 13/9/2016 \\ Aprovado em 11/10/2016}

\section{Referência bibliográfica}

IAMAMOTO, M.; CARVALHO, Raul. Relações sociais e Serviço Social no Brasil. São Paulo: Cortez/Celats, 1983. 